\title{
Tuber donnagotto, a new winter truffle species from Istria, Croatia
}

\author{
ROMANO BoŽAC, IVAN ŠIRIĆ*, IVICA KoS \\ University of Zagreb Faculty of Agriculture, Svetošimunska 25, 10000 Zagreb, Croatia
}

\begin{abstract}
Tuber donnagotto is a new winter black truffle belonging to the order Pezizales and the family Tuberaceae. It grows in winter in the calcareous gravel soil $(\mathrm{pH}$ 7.6-7.8) near the Adriatic Sea (Rovinj, Istria, Croatia) in predominantly pine forests (Pinus halepensis). Although similar to other black truffles, it has very irregular and hard fruit bodies, lobate and knotted in form, with deep irregular cavities reaching the middle of the fruit bodies. These cavities are clearly evident in the cross-section of the fruit bodies. A distinctive characteristic of this truffle is the fact that when it is hermetically closed it can be kept in a refrigerator $\left(2-4^{\circ} \mathrm{C}\right)$ for more than 60 days. Tuber donnagotto has a slight but pleasant odor, reminiscent of boletus (Boletus reticulates, B. edulis). Furthermore, $T$. donnagotto has yellow-brownish and reticulate-alveolate spores, measuring $20-30 \times 20-25 \mu \mathrm{m}$.
\end{abstract}

Key words: Mushroom, Pinus, spores, Tuber donnagotto, Istria, Croatia

\section{Introduction}

A major scientific contribution to underground mushrooms was made many years ago by the Italian (VITTAdini 1831, SACARdo 1895, MATTIROLO 1887) and French researchers (Tulasne and Tulasne 1851). Ceruti et al. (2003) made a historical revision of the European Tuber species from the 18th to the 20th century. According to this study, 35 valid species, varieties and forms that belong to the genus Tuber are known today in Europe. Based on the revision of the genus Tuber and the analysis of ITS sequences of rDNA (Roux et al. 1999), CERUTI et al. (2003) do not recognize Tuber aestivum var. uncinatum Chatin (CHEVALIER et al. 1979) as a valid species. They think it is just a synonym for Tuber aestivum Vittad. MonTECCHI and SARASINI (2000) described 11 species, varieties and forms that belong to a group of black colored truffles (Tuber brumale Vittad., T. brumale var. moscatum (Ferry) Montecchi and Lazzari, T. melanosporum Vittad., T. indicum Cooke and Masse, T. macrosporum Vittad., T. malenconii Donadini, Riousset and Chevalier, T. bellonae Quel., T. mesentericum Vittad., T. regianum Montecchi and Lazzari, T. aestivum and T. aestivum

\footnotetext{
* Corresponding author, e-mail: isiric@agr.hr Copyright $^{\circledR} 2012$ by Acta Botanica Croatica, the Faculty of Science, University of Zagreb. All rights reserved.
} 
var. uncinatum (Chatin) Montecchi and Borelli. All these species grow in Europe except Tuber indicum (which grows in China) and are used for commercial purposes. Scientific research into underground fungi began in Italy, where it was undertaken by VITTADINI (1831), Saccardo (1892), Mattirolo (1910), Ceruti (1961). Researchers in France include TUlASNE (1844), QuelET $(1873,1883)$ and later many other mycologists worldwide. In Croatia underground mushrooms have not been scientifically studied and no research papers on truffles and other mushrooms found below the surface of the soil have been published to this day. In other countries of the former Yugoslavia (Serbia, Montenegro and Macedonia) the ecological specificities and molecular diversity of truffles have been investigated by MARJANOVIĆ et al. (2010). The authors described twelve Tuber species, including five varieties of Tuber rufum Pico and concluded that the ecosystem conditions of Balkan Peninsula support truffle production.

A new species of truffle, Tuber donnagotto, belonging to a group of black colored truffles, has been described for the first time in this paper. It was found on the northern Adriatic coast (Rovinj, Istria, Croatia) in predominantly pine forest (Pinus halepensis Mill.) on the calcareous-gravel soil (pH 7.6-7.8).

\section{Materials and methods}

The truffles were found on November 15 and December 18, 2010, January 15, February 20, March 13, and April 3, 2011, on the Adriatic coast (Rovinj, Istria, Croatia). The concentration of hydrogen ions $(\mathrm{pH})$ of soil was measured in an aqueous solution using the IQ 150 $\mathrm{pH}$ meter (IQ scientific Instruments, USA). The microscopy and measurement of morphological details of the truffles were carried out using a Carl Zeiss Jena microscope. The recording of the morphological structure was performed using a Carl Zeiss Jenamed 2 microscope, and the Camedo C-5050 ZOOM, Olympus camera (Japan).

\section{Results}

\section{Description of the new species}

Tuber donnagotto Božac, Širić et Kos, sp. nov.

\section{MYCOBANK MB 563709}

Etymology. In honor of the dogs (Donna et Gotto) of the breed Lagotto Romagnolo that found the truffles.

\section{Diagnosis Latina}

Tuber donnagotto est species nova tuberis nigri, autumno crescentis, mycorrhizas cum pinibus (Pinus halepensis Mill.) formantis. Peridium eius verrucis atris irregularibus et polygonalibus, $150-450 \mu \mathrm{m}$ crassum, structurā pseudoparenchymaticā, cellulis polygonalibus 9-12 $\mathrm{mm}$ latis. Ascocarpia atra, admodum irregularia, tuberiformia, lobos aut eminentias habentia. Gleba cerea, venis albis densis et sinuosis marmorata, cuius in sectione transversa cavae irregulares manifeste visibiles. Odor lenis et iucundus, Boletus edulis Bull.ex Fries. Asci globosi aut subglobosi, 55-90 × 65-75 $\mu \mathrm{m}, 1-7$ ascosporas 
continentes. Ascosporae ipsae fulvo-fuscae, late ellipsoideae aut subglobosae, 20-30 ×

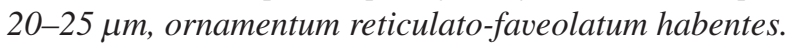

\section{Morphology}

The fruit bodies are hypogeous or subepigeous, black, warted, very irregular, rounded, tuberiform, lobed or knotty, irregular and deeply furrowed (Fig. 1a), with a more or less evident apical opening; irregular cavities of various shapes and sizes are clearly visible on the cross-section (Fig. 1b), the average diameter is $2-7 \mathrm{~cm}$, they are as hard as stone and are similar to Tuber excavatum Vittad.

The peridium is $150-450 \mu \mathrm{m}$ thick, the structure is pseudoparenchymatous with polygonal cells 9-20 $\mu \mathrm{m}$ wide, on the peripheral part they are black-brown, the yellowish-brown inner layers are composed of irregular polygonal warts of different sizes, in some places they are higher and in some places smaller, flattened or slightly depressed at the center, sometimes reddish at the base, only rare warts have one or two radial ridges or fissures, dense parallel transversal striate which form a polygonal surface, clearly visible with a lens (Fig. 1d).

The gleba is whitish when very young, at full maturity it is light brown, marbled by dense white veins. The veins are short and very meandriform at the cross-section (Fig. 1c). The odor of the young fruit bodies is very slight or completely absent, at full maturity it is pleasant and reminiscent of boletus (Boletus reticulatus Shaeff., Boletus edulis Bull. ex Fries).

Most asci are spherical, a few of them (about 5\%) are subglobose hyaline, measuring $55-80-90 \times 65-75 \mu \mathrm{m}$, containing 1-7 spores, usually 4-6, the length of the pedicle is $15-20 \mu \mathrm{m}$. The spores are yellowish-brown, ellipsoid to spherical, size 20-30 $\times 20-25 \mu \mathrm{m}$ measured excluding ornamentation. They have a reticulate-alveolate ornament with irregular polygonal meshes (Fig. 1e). The reticulum has slightly prominent aculei in correspondence with knots, the meshes are 3-4 $\mu \mathrm{m}$ high and 5-8 $\mu \mathrm{m}$ wide, numbering 3-4 along the bigger spore dimension. Q (length / width) $=1.1-1.2-1.5$.

\section{Habitat}

Their habitat is predominantly pine forests (Pinus halepensis) near the sea, from November to April in gravelly red soil, $\mathrm{pH}$ 7.6-7.8. At the first harvest (November 15, 2010) almost all fruit bodies were on the surface of the soil (semi-epigeous), at the second harvest (December 18, 2010) the truffles were bigger $(4-7 \mathrm{~cm})$ and were found deeper in the soil $(5-10 \mathrm{~cm})$, while at the third harvest (February 20,2011) almost all the fruit bodies were on the surface (semi-epigeous) on which grass does not grow. During its growth the Tuber donnagotto probably produces substances (allelochemicals) that inhibit growth and reproduction of grasses.

Additional specimens examined. CROATIA. ISTRIAN PENINSULA: Rovinj, $35 \mathrm{~km}$ NE of Pula $\left(45^{\circ} 04^{\prime} 17.19^{\prime \prime} \mathrm{N}, 13^{\circ} 38^{\prime} 15.5^{\prime \prime} \mathrm{E}\right), 9$ meters above the mean sea level, in symbiosis with Pinus halepensis, leg. R. Božac, November 15, 2010, December 18, 2010, February 20, 2011, March 13, and April 3, 2011. 

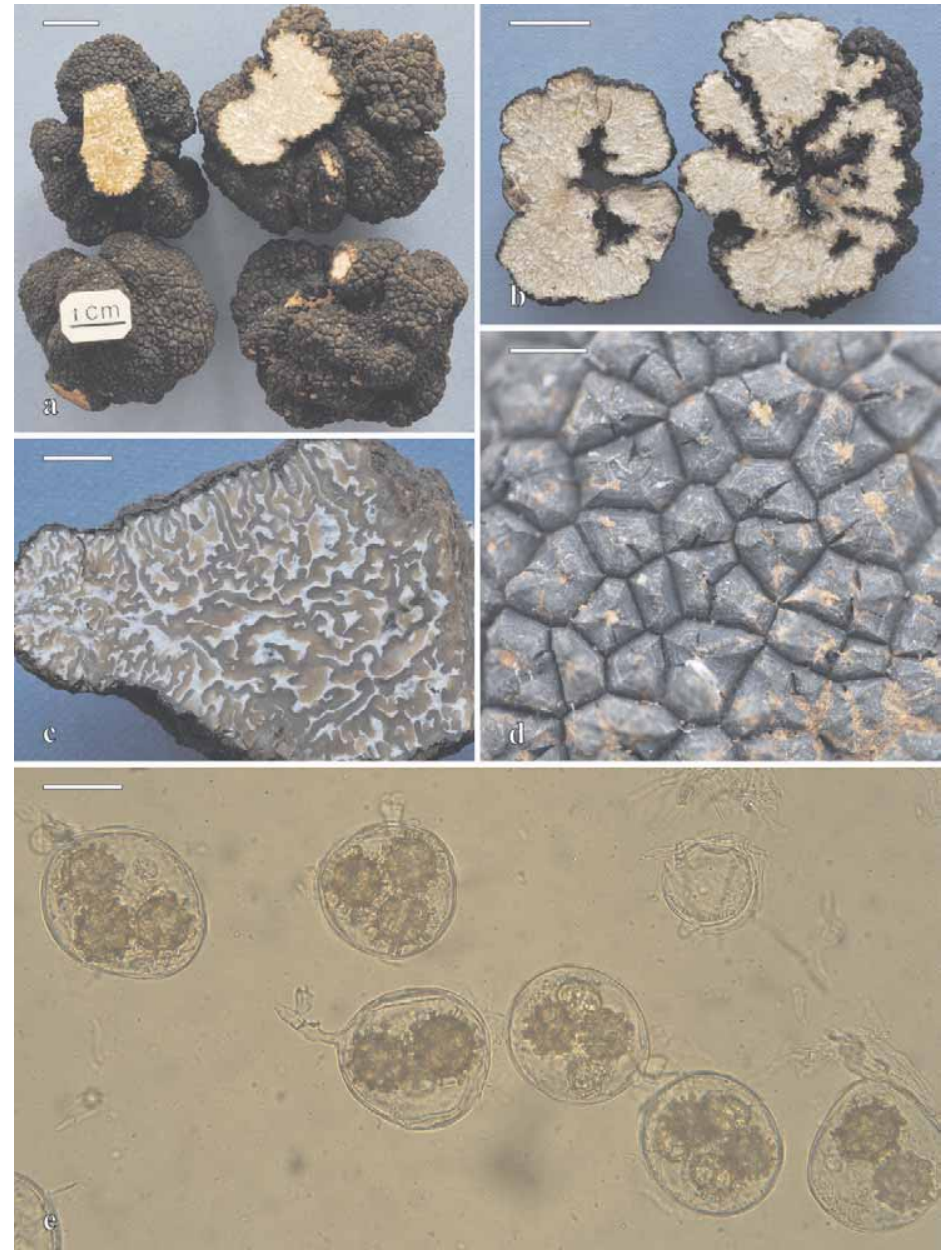

Fig. 1. Tuber donnagotto (holotype). a - fruit bodies; b - cross section of fruit bodies; $\mathrm{c}-$ cross section of matured fruit body; $\mathrm{d}$ - warts of peridium; e - asci and ascospores. Bars denote $1 \mathrm{~cm}(\mathrm{a}, \mathrm{c}), 2 \mathrm{~cm}(\mathrm{~b}), 2 \mathrm{~mm}(\mathrm{~d}), 30 \mu \mathrm{m}(\mathrm{e})$.

\section{Discussion}

The new underground species belongs to a group of black truffles 10 species, varieties and forms of which were previously known in Europe (MONTECCHI and SARASINI 2000, CERUTI et al. 2003). Due to the great external similarity of black truffles, commercial collectors often mistake one for another. The well known black truffle Tuber melanosporum grows at the same time and can be found in the same habitat as the Tuber donnagotto.

The most significant morphological differences of Tuber donnagotto in relation to similar black truffles (Tuber brumale and T. melanosporum) that grow at the same time (autumn and winter) are color (black, black-brown), form (warted, very irregular, rounded, tuberiform, lobed or knotty, and deeply furrowed), size and ornamentation of spores (20-30 x 20-25 $\mu \mathrm{m}$ and reticulate-alveolate ornament with irregular polygonal meshes), size and 
hardness of fruit bodies (the average diameter 2-7 cm and hard fruit bodies), cross section (irregular cavities of various shapes and sizes are clearly visible), gleba (whitish when very young, at full maturity light brown, marbled by dense white veins), odor and taste (the odor of young fruit bodies is very slight or completely absent, at full maturity it is pleasant and reminiscent of boletus) and per time of viability in a refrigerator (more than 60 days). All the other European species of black truffles grow in the spring, summer and autumn and have a more regular form, significantly different odor and taste and significantly lower viability in a refrigerator.

During growth Tuber melanosporum produces allelochemicals that inhibit the growth and reproduction of grass (RIOUSSET et al. 2001). Tuber melanosporum is significantly different from Tuber donnagotto because it has regular and bigger fruit bodies, its peridium has much bigger warts, the gleba is blackish-brown with purple tinges, its odor is characteristic and pleasant, the spores are dark colored, blackish-brown and densely ornamented with single spines (CERUTI et al. 2003). Other similar black truffles, which grow at the same time and in similar habitats, are Tuber brumale and Tuber brumale var. moscatum. However, the quality of the new species in comparison with these black truffles is unquestionable. The mentioned truffles have more regular fruit bodies, Tuber brumale has a gray-black gleba and form moscatum has a beige-hazel-brown gleba. The odor is strong and persistent: according to VITTADINI (1831) it is similar to that of the cortex of Cornus sanguinea $\mathrm{L}$., the spores are hazel-brown and densely ornamented with single spines. The Tuber bellone is also similar in color and can grow at the same time (it was found on January 15, 2011, Rovinj, Istria, Croatia), but in symbiosis with Quercus ilex L. What is more, the peridium has pyramidal warts with smooth side surfaces, never transversally striate (CERUTI et al. 2003), the asci are ovoid, 77-115 × 77-95 $\mu \mathrm{m}$, the spores are yellow-ochre, spherical and reticulate-alveolate, the odor is distinctly phenolic when is fresh, and then more pleasant (MONTECHI and SARASINI 2000). The Tuber aestivum is significantly different because it grows in spring and summer, the fruit bodies are rounded and more or less regular, the peridium has much larger pyramidal warts whose base is never reddish. The asci have saccate form, shortly pedununculate, $80-100 \times 50-80 \mu \mathrm{m}$, the odor is pleasant, reminiscent of roast barley malt or fermenting matter. The somewhat similar Tuber malenconii grows in symbiosis with Quercus ilex, Q. ilex subsp. ballota (Desf.) Samp, and Q. coccifera $\mathrm{L}$. Its fruit bodies are much smaller, the peridium is composed of small and not very prominent pyramidal warts which turn red or yellow when rubbed. The asci are 60-80 $\mu \mathrm{m}$ wide and contain up to 6-8 spores. With time the odor of this species becomes more and more unpleasant, fecal or cabbage-like or garlicky. The spores are reticulate-alveolate with very small and dense meshes, the average numbering 6-8 along the bigger dimension (DonAdini et al. 1978). The Tuber mesentericum has distinctly coarser (larger) pyramidal verrucae, the gleba is light hazel-brown at full maturity, the odor is generally very strong in just collected fruit bodies, reminiscent of tar and iodine (MONTECCHI and SARASINI 2000). Tuber regianum has tuberiform or subglobose fruitbodies, $1.5-3 \mathrm{~cm}$ in diameter, dark brown or blackish red, the surface is glabrous or finely areolate-verrucose or with very small papillae (MONTECCHI and LAZZARI 1987).

Tuber donnagotto is substantially different from all known species of black truffles. No other known species of black truffle has such irregular fruit bodies with deep and irregular grooves (Fig. 1a, b). Moreover, unlike all other black truffles, the fruit bodies of the new species can be kept in a refrigerator $\left(2-4{ }^{\circ} \mathrm{C}\right)$ for more than 60 days. The fruitbodies_are very hard, similar to Tuber excavatum and are never attacked by insects or nematodes. 


\section{References}

Ceruti, A., 1961: Revisione di alcune specie di Elafomicetali e di Tuberali dell America del nord. Allionia 7, 1-25.

Ceruti, A., Fontana, A., Nosenzo, C., 2003: Le specie Europee del genere Tuber Una revisione storico, Museo Regionale di Scienze Naturali, Torino.

Chevalier, G., Delmas, C., Frochot, H., Riousset L., 1979: L'espèce Tuber aestivum Vitt.: I. definition. Mushroom Science 109, 57-975.

Donadini, J. C., Riousset, L., Riousset, G., Chevalier, G., 1978: Tuber malenconii nov. sp. Bulletin de la Société Mycologique de France 94, 351-358.

Marjanović, Ž., Grebenec, T., Marković, M., Glišić, A., Milenković, M., 2010: Ecological specificities and molecular diversity of truffles (genus Tuber) originating from mid-west Balkan Peninsula. Sydowia 62, 67-87.

Mattirolo, O., 1887: Sul parassitismo dei Tartufi e sulla questione Mycorrhizae. Malpighia 1, 359-369.

MAtTiRolo, O., 1910: I tartufi, loro coltivazione e rapporti con il rimboschimento e colla crisi viticola. L' Alpe 8, 1-31.

Montecchi, A., LAZZARI, G., 1987: Un nuovo tartufo di montogna: Tuber regianum s.sp. Rivista di Micologia 30, 3-11.

Montecchi, A., Sarasini, M., 2000: Funghi ipogei d'Europa, Centro Studi Micologici, Associazione Micologica Bresadola, Trento.

Quelet, L., 1873: Les champignons du Jura et des Vosges. Memoires de la Societe d'Emulation 5, 333-427.

QuELET, L., 1883: Quelques espécés critiques ou nouvelles de la Flore mycologique de France. Comptes Rendus de l'Association Francaise pour l'Avancemet des Sciences 11, $387-412$.

Riousset, L., Riousset, G., Chevalier, G., Bardet, M., 2001: Truffes d'Europe et de Chine. Inra Editions, Paris.

Roux, C., Sejalon-Delmas, N., Martins, M., Parguey-Leduc, A., Dargent, R., Becard, G., 1999: Phylogenetic relationships between European and Chinese truffles based on parsimony and distance analysis of ITS sequences. FEMS Microbiology Letters 164, $147-155$.

SaCcardo, P. A., 1892: Tuberoidae Vitt., Sylloge fungarum ommium hucusque cognitorum. Supplementum universale 2, 10, 80-83.

SACCARDO, P. A., 1895: Tuberoidae Vitt., Sylloge fungarum ommium hucusque cognitorum. Supplementum universale 3, 11, 411-445.

Tulasne, L. R., Tulasne, C., 1844: Fungi nonnulli hypogaei, novi vel minus cogniti. Giornale Botanico Italiano 2, 55-63.

Tulasne, L. R., Tulasne, C., 1851: Fungi hypogaei: Historie et monographie champignons hypoges, Friedrich Kfincksieck, Paris.

VitTAdini, C., 1831: Monographia Tuberacearum ex Typographia. Felicis Rusconi, Milano. 